\title{
Maternal Thyroid Disorders, Labor Complications and Preterm Delivery
}

\author{
Ahmed RG* \\ Division of Anatomy and Embryology, Department of Zoology, Beni Suef University, Egypt
}

Submission: February 19, 2018; Published: March 15, 2018

*Corresponding author: Ahmed RG, Division of Anatomy and Embryology, Department of Zoology, Beni Suef University, Egypt,

Tel/Fax: 002-010-91471828; Email: ahmedragab08@gmail.com

Abbreviations: T3: Triiodothyronine; TSH: Thyroid Stimulating Hormone; TPOAb: Thyroperoxidase Antibody; Hcg: Human Chorionic Gonadotropin; BMI: Body Mass Index

\section{Commentary}

The normal behavior of delivery process is dependent on the normal supply of maternal thyroid hormones (THs; Thyroxine (T4) and 3,5,3-triiodothyronine (T3)) [1-77]. On the other hand, abnormalities in the activities of maternal thyroid function or thyroid autoimmunity may be increased the risk of the preterm birth [78]. In addition, [73] reported that congenital hypothyroidism with disorders in the levels of thyroid-stimulating hormone (TSH) can cause premature infants born at less than 30 weeks gestation. [71] Postulated that the congenital hypothyroidism can cause preterm delivery and severely decrease the birth and neonatal weight. Also, the subclinical hypothyroidism can cause a miscarriage in both the first and second trimester [77-82]. However, the subclinical hyperthyroidism does not alter the rate of preterm birth [63].

More interestingly, [80-83] recorded that the elevation in the rate of spontaneous miscarriage and preterm delivery can be attributed to the occurrence of thyroid antibodies in euthyroid pregnant [84]. These explanations strengthen the possibility that the thyroid autoimmunity rigorously diminished the thyroidal response to human chorionic gonadotropin (hCG) stimulation and that this might increase the risk of premature delivery in thyroperoxidase antibody (TPOAb)-positive women $[85,64,74,75]$. Also, the previous results are in concordance with those of the study carried out by $[69,79,84]$ who reported that the gestational hypothyroidism is associated with an increased risk of intrauterine fetal death, habitual abortion, fetal retardation, anemia, fetal congenital anomalies, cardiac dysfunction, postpartum bleeding, and post-partum depression. This is probably can cause several adverse maternal, fetal and neonatal outcomes including the perinatal morbidity and mortality $[66,81,77]$.

Beside the thyroid disorders, there are several causes of preterm delivery such as multiple gestations, low body mass index (BMI) before pregnancy, African-American race, short cervix, intrauterine infection and increase the concentration of fetal fibronectin during the second half of pregnancy [70]. From the correlation between the previous observations and the current view, it can be inferred that the stability in the maternal hypothalamus-pituitary-thyroid axis (HPTA) displays substantial actions during the gestation and labor [86]. As well, the dysregulations in the levels of maternal THs may cause preterm delivery and several labor complications. These persistent problems may indicate the presence of several neonatal disorders in the future. However, these complications are complex and serious. Thus, following the activities of thyroid gland before the gestation may be essential to avoid the preterm delivery and labor problems. In addition, additional examinations are wanted to recognize and treat thyroid disorders with the goal of preventing the preterm delivery and several labor complications.

\section{References}

1. Abalovich M, Gutierrez S, Alcaraz G, Maccallini G, Garcia, A, et al (2002) Overt and subclinical hypothyroidism complicating pregnancy. Thyroid 12(1): 63-68.

2. Ahmed OM, Abd El Tawab SM, Ahmed RG (2010) Effects of experimentallyinduced maternal hypothyroidism and hyperthyroidism on the development of rat offspring: I- The development of the thyroid hormones-neurotransmitters and adenosinergic system interactions. International Journal of Developmental Neuroscience 28(6): 437-454. 
3. Ahmed OM, Ahmed RG (2012) Hypothyroidism. In A New Look At Hypothyroidism, Dr. D. Springer (Edn), In Tech Open Access Publishers 1: 1-20.

4. Ahmed OM, Ahmed RG, El Gareib AW, ElBakry AM, Abd El Tawaba SM (2012) Effects of experimentally induced maternal hypothyroidism and hyperthyroidism on the development of rat offspring: II-The developmental pattern of neurons in relation to oxidative stress and antioxidant defense system. International Journal of Developmental Neuroscience 30(6): 517-537.

5. Ahmed OM, El Gareib AW, El bakry AM, Abd El Tawab SM, Ahmed RG (2008) Thyroid hormones states and brain development interactions. International Journal of Developmental Neuroscience 26(2): 147-209.

6. Ahmed RG (2011) Perinatal 2, 3, 7, 8-tetrachlorodibenzo-p-dioxin exposure alters developmental neuroendocrine system. Food Chem Toxicology 49: 1276-1284.

7. Ahmed RG (2012) a. Maternal-newborn thyroid dysfunction. In the Developmental Neuroendocrinology, LAP LAMBERT Academic Publishing GmbH \& Co KG, Germany pp. 1-369.

8. Ahmed RG (2012) b. Maternal-fetal thyroid interactions, Thyroid Hormone, Dr NK Agrawal (Edn.), In Tech Open Access Publisher 5:125156

9. Ahmed RG (2013) Early weaning PCB 95 exposure alters the neonatal endocrine system: thyroid adipokine dysfunction. The Journal of Endocrinology 219(3): 205-215.

10. Ahmed RG (2014) Do PCBs modify the thyroid-adipokine axis during development? Annals Thyroid Res 1(1): 11-12.

11. Ahmed RG (2015) a. Chapter 1: Hypothyroidism and brain development. In advances in hypothyroidism treatment, Avid Science Borsigstr 9, 10115 Berlin, Berlin, Germany, Avid Science Publications level 6, Melange Towers, Wing a, Hitec City, Hyderabad, Telangana, India, pp. 1-40.

12. Ahmed RG (2015) b. Hypothyroidism and brain developmental players. Thyroid Research J 8(2): 1-12.

13. Ahmed RG (2015) c. Editorials and Commentary: Maternofetal thyroid action and brain development. J of Advances in Biology 7(1): 12071213.

14. Ahmed RG (2016) a. Gestational dexamethasone alters fetal neuroendocrine axis. Toxicology Letters 258: 46-54.

15. Ahmed RG (2016) b. Neonatal polychlorinated biphenyls-induced endocrine dysfunction. Annals Thyroid Res 2(1): 34-35.

16. Ahmed RG (2016) c. Maternal iodine deficiency and brain disorders. Endocrinology \& Metabolic Syndrome 5: 223.

17. Ahmed RG (2016) d. Maternal bisphenol A alters fetal endocrine system: Thyroid adipokine dysfunction. Food and Chemical Toxicology 95: 168-174.

18. Ahmed RG (2017) a. Developmental thyroid diseases and GABAergic dysfunction. EC Neurology 8(1): 02-04.

19. Ahmed RG (2017) b. Hyperthyroidism and developmental dysfunction Archives of Medicine 9(4): 6.

20. Ahmed RG (2017) c. Anti-thyroid drugs may be at higher risk for perinatal thyroid disease. EC Pharmacology and Toxicology 4(4): 140142

21. Ahmed RG (2017) d. Perinatal hypothyroidism and cytoskeleton dysfunction. Endocrinology \& Metabolic Syndrome 6(4): 271.

22. Ahmed RG (2017) e. Developmental thyroid diseases and monoaminergic dysfunction. Advances in Applied Science Research 8(3): 01-10.
23. Ahmed RG (2017) f. Hypothyroidism and brain development. Journal of Animal Research and Nutrition 2(2): 13.

24.Ahmed RG (2017) g. Antiepileptic drugs and developmental neuroendocrine dysfunction: Every why has A Wherefore. Archives of Medicine 9(6): 2 .

25. Ahmed RG (2017) h. Gestational prooxidant-antioxidant imbalance may be at higher risk for postpartum thyroid disease. Endocrinology \& Metabolic Syndrome 6(5): 279.

26. Ahmed RG (2017) i. Synergistic actions of thyroid-adipokines axis during development. Endocrinology \& Metabolic Syndrome 6(6): 280.

27. Ahmed RG (2017) j. Thyroid-insulin dysfunction during development. International Journal of Research Studies in Zoology 3(4): 73-75.

28. Ahmed RG (2017) k. Developmental thyroid diseases and cholinergic imbalance. International Journal of Research Studies in Zoology 3(4): $70-72$

29. Ahmed RG (2017) l. Thyroid diseases and developmental adenosinergic imbalance. International Journal of Clinical Endocrinology 1(2): $053-$ 055 .

30.Ahmed RG (2017) m. Maternal anticancer drugs and fetal neuroendocrine dysfunction in experimental animals. Endocrinology \& Metabolic Syndrome 6(6): 281

31. Ahmed RG (2017) n. Letter: Gestational dexamethasone may be at higher risk for thyroid disease developing peripartum. Open Journal of Biomedical \& Life Sciences (Ojbili) 3(2): 01-06.

32. Ahmed RG (2017) o. Deiodinases and developmental hypothyroidism EC Nutrition 11(5): 183-185

33. Ahmed RG (2017) p. Maternofetal thyroid hormones and risk of diabetes. International Journal of Research Studies in Medical and Health Sciences 2(10): 18-21.

34. Ahmed RG (2017) r. Association between hypothyroidism and renal dysfunctions. International Journal of Research Studies in Medical and Health Sciences 2(11): 1-4.

35. Ahmed RG (2017) s. Maternal hypothyroidism and lung dysfunction International Journal of Research Studies in Medical and Health Sciences 2(11): 8-11.

36. Ahmed RG (2017) t. Endocrine disruptors; possible mechanisms for inducing developmental disorders. International journal of basic science in medicine (IJBSM) 2(4): 157-160.

37. Ahmed RG (2017) u. Maternal thyroid hormones trajectories and neonatal behavioral disorders. ARC Journal of Diabetes and Endocrinology 3(2): 18-21.

38. Ahmed RG (2017) v. Maternal thyroid dysfunction and neonatal cardiac disorders. Insights in Biology and Medicine 1: 092-096.

39. Ahmed RG (2018) a. Maternal hypothyroidism and neonatal testicular dysfunction. International Journal of Research Studies in Medical and Health Sciences 3(1): 8-12.

40.Ahmed RG (2018) b. Maternal hypothyroidism and neonatal depression: Current perspective. International Journal of Research Studies in Zoology 4(1): 6-10.

41. Ahmed RG (2018) c. Non-genomic actions of thyroid hormones during development. App ClinPharmacolToxicol ACPT: 108.

42. Ahmed RG (2018) d. Maternal thyroid function and placental hemodynamics. ARC Journal of Animal and Veterinary Sciences 4(1): 9-13.

43. Ahmed RG (2018) e. Interactions between thyroid and growth factors during development. ARC Journal of Diabetes and Endocrinology 4(1): $1-4$ 
44. Ahmed RG (2018) f. Maternal thyroid hormones and neonatal appetite. ARC Journal of Nutrition and Growth 4(1): 18-22.

45. Ahmed RG (2018) g. Genomic actions of thyroid hormones during development. ARC Journal of Diabetes and Endocrinology 4(1): 5-8.

46. Ahmed RG (2018) h. Dysfunction of maternal thyroid hormones and psychiatric symptoms. American Research Journal of Endocrinology 2(1): 1-6.

47. Ahmed RG (2018) i. Is there a connection between maternal hypothyroidism and developing autism spectrum disorders? ARC Journal of Neuroscience 3(1): 5-8.

48. Ahmed RG (2018) j. Maternal thyroid dysfunctions and neonatal bone maldevelopment. American Research Journal of Endocrinology.

49. Ahmed RG (2018) k. Maternal thyroid disorders and risk of neonatal seizure: Current perspective. ARC Journal of Neuroscience 3(1): 21-25.

50. Ahmed RG (2018) l. Gestational dioxin acts as developing neuroendocrine-disruptor. EC Pharmacology and Toxicology 6(3): 96100.

51. Ahmed RG, Abdel Latif M, Ahmed F (2015) a. Protective effects of GM-CSF in experimental neonatal hypothyroidism. International Immunopharmacology 29(2): 538-543.

52. Ahmed RG, Abdel Latif M, Mahdi EA, El Nesr KA (2015) b. Immune stimulation improves endocrine and neural fetal outcomes in a model of maternofetal thyrotoxicosis. International Immunopharmacology 29(2): 714-721.

53. Ahmed RG, Davis PJ, Davis FB, De Vito P, Farias RN, et al. (2013) a. Nongenomic actions of thyroid hormones: from basic research to clinical applications. An update. Immunology, Endocrine \& Metabolic Agents in Medicinal Chemistry 13(1): 46-59.

54. Ahmed RG, El Gareib AW (2014) Lactating PTU exposure: I- Alters thyroid-neural axis in neonatal cerebellum. European Journal of Biology and Medical Science Research 2(1): 1-16.

55. Ahmed RG, El Gareib AW (2017) Maternal carbamazepine alters fetal neuroendocrine-cytokines axis. Toxicology 382: 59-66.

56. Ahmed RG, El Gareib AW, Incerpi S (2014) Lactating PTU exposure: II- Alters thyroid-axis and prooxidant-antioxidant balance in neonatal cerebellum. International Reserach Journal of Natural Sciences 2(1) 1-20.

57. Ahmed RG, El Gareib AW, Shaker HM (2018) a. Gestational $3,3^{\prime}, 4,4^{\prime}, 5$-pentachlorobiphenyl (PCB 126) exposure disrupts fetoplacental unit: Fetal thyroid-cytokines dysfunction. Life Sciences 192: 213-220.

58. Ahmed RG, Incerpi S (2013) Gestational doxorubicin alters fetal thyroid-brain axis. International Journal of Developmental Neuroscience 31(2): 96-104.

59. Ahmed RG, Incerpi S, Ahmed F, Gaber A (2013) b. The developmental and physiological interactions between free radicals and antioxidant: Effect of environmental pollutants. Journal of Natural Sciences Reserach 3(13): 74-110.

60. Ahmed RG, Walaa GH, Asmaa FS (2018) b. Suppressive effects of neonatal bisphenol A on the neuroendocrine system. Toxicology and Industrial Health Journal (in press).

61. Allan WC, Haddow JE, Palomaki GE, Williams JR, Mitchell ML (2000) Maternal thyroid deficiency and pregnancy complications: implications for population screening. Journal of Medical Screening 7(3): 127-130.

62. Candelotti E, De Vito P, Ahmed RG, Luly P, Davis PJ, et al. (2015) Thyroid hormones crosstalk with growth factors: Old facts and new hypotheses. Immunology, Endocrine \& Metabolic Agents in Medicinal Chemistry 15(1): 71-85.
63. Casey BM, Dasehe JS, Wells CE, McIntire DD, Leveno KJ, et al. (2006) Subclinical hyperthyroidism and pregnancy outcomes. Obstetrics \& Gynecology 107(2 Pt 1): 337-341.

64. Chan S, Boelaert K (2015) Optimal management of hypothyroidism, hypothyroxinaemia and euthyroid TPO antibody positivity preconception and in pregnancy. Clinical Endocrinology (Oxf) 82(3): 313-326.

65. De Vito P, Candelotti E, Ahmed RG, Luly P, Davis PJ (2015) Role of thyroid hormones in insulin resistance and diabetes. Immunology, Endocrine \& Metabolic Agents in Medicinal Chemistry 15(1): 86-93.

66. Demissie K, Rhoads GG, Ananth CV, Alexander GR, Kramer MS, et al. (2001) Trends in preterm birth and neonatal mortality among blacks and whites in the United States from 1989 to 1997. American Journal of Epidemiology 154(4): 307-315.

67. El bakry AM, El Ghareeb AW, Ahmed RG (2010) Comparative study of the effects of experimentally-induced hypothyroidism and hyperthyroidism in some brain regions in albino rats. International Journal of Developmental Neuroscience 28(5): 371-389.

68. El Ghareeb AA, El Bakry AM, Ahmed RG, Gaber A (2016) Effects of zinc supplementation in neonatal hypothyroidism and cerebellar distortion induced by maternal carbimazole. Asian Journal of Applied Sciences 4(4): 1030-1040.

69. Glinoer D, Delange F (2000) The potential repercussions of maternal, fetal, and neonatal hypothyroxinemia on the progeny. Thyroid $10(10)$ 871-887.

70. Goldenberg RL, Culhane JF, Iams JD, Romero R (2008) Preterm birth 1: epidemiology and causes of preterm birth. Lancet 371(9706): 75-84.

71. Hashemipour M, Hovsepian S, Ansari A, Keikha M, Khalighinejad P, et al. (2018) Screening of congenital hypothyroidism in preterm, low birth weight and very low birth weight neonates: A systematic review. Pediatrics and Neonatology 59(1): 3-14.

72. Incerpi S, Hsieh MT, Lin HY, Cheng GY, De Vito P, et al. (2014) Thyroid hormone inhibition in L6 myoblasts of IGF-I-mediated glucose uptake and proliferation: new roles for integrin $\alpha v \beta 3$. American Journal of Physiology Cell Physiology 307(2): C150-C161.

73. Kaluarachchi DC, Colaizy TT, Pesce LM, Tansey, M, Klein JM (2017) Congenital hypothyroidism with delayed thyroid-stimulating hormone elevation in premature infants born at less than 30 weeks gestation. Journal of Perinatology 37(3): 277-282

74. Korevaar TI, Steegers EA, de Rijke YB, Schalekamp Timmermans, S, Visser WE, et al. (2015) Reference ranges and determinants of total hCG levels during pregnancy: the Generation R Study. European Journal of Epidemiology 30(9): 1057-1066.

75. Korevaar TI, Steegers EA, Pop VJ, Broeren MA, Chaker L, et al. (2017) b. Thyroid autoimmunity impairs the thyroidal response to human chorionic gonadotropin: two population-based prospective cohort studies. The Journal of Clinical Endocrinology and Metabolism 102(1): 69-77.

76. Korevaar TI, Steegers EAP, Chaker L, Medici M, Jaddoe VWV, et al. (2017) a. Thyroid function and premature delivery in TPO antibodynegative women: The added value of hCG. The Journal of Clinical Endocrinology and Metabolism 102(9): 3360-3367.

77. Lara MC, Sánchez ÁV, Solano CC, Pazos ES, Álvarez MI, et al. (2017) Hypothyroidism screening during first trimester of pregnancy. BMC Pregnancy and Childbirth 17(1): 438.

78. Li M, Wang SW, Wu FL, Shi J, Yu PL, et al. (2016) Ethnic differences in preterm birth risks for pregnant women with thyroid dysfunction or autoimmunity: A meta-analysis. Biomedical and Environmental Sciences 29(10): 724-733. 
79. Mandel SJ (2004) Hypothyroidism and chronic autoimmune thyroiditis in the pregnant state: maternal aspects. Best Practice \& Research Clinical Endocrinology \& Metabolism 18(2): 213-224.

80. Negro R, Schwartz A, Stagnaro Green A (2016) Impact of levothyroxine in miscarriage and preterm delivery rates in first trimester thyroidantibody-positive women with TSH less than 2.5 $\mathrm{mIU} / \mathrm{L}$. The Journal of Clinical Endocrinology and Metabolism 101(10): 3685-3690.

81. Stagnaro Green A (2009) Maternal thyroid disease and preterm delivery. The Journal of Clinical Endocrinology and Metabolism 94(1): 21-25.

82. Stagnaro Green A, Glinoer D (2004) Thyroid autoimmunity and the risk of miscarriage. Best Practice \& Reserach Clinical Endocrinology \& Metabolism 18(2): 167-181.
83. Stagnaro Green A, Roman SH, Cobin RH, El Harazy E, Alvarez Marfany M, et al. (1990) Detection of at-risk pregnancy by means of highly sensitive assays for thyroid antibodies. JAMA 264(11): 1422-1425.

84. Tudosa R, Vartej P, Horhoianu I, Ghica C, Mateescu S, et al. (2010) Maternal and fetal complications of the hypothyroidism-related pregnancy. Maedica, A Journal of Clinical Medicine 5(2): 116- 23.

85. Unuane D, Velkeniers B, Anckaert E, Schiettecatte J, Tournaye H, et al. (2013) Thyroglobulin autoantibodies: is there any added value in the detection of thyroid autoimmunity in women consulting for fertility treatment? Thyroid 23(8): 1022-1028.

86. Van Herck SLJ, Geysens S, Bald E, Chwatko G, Delezie E, et al. (2013) Maternal transfer of methimazole and effects on thyroid hormone availability in embryonic tissues. The Journal of Endocrinology 218(1): 105-115.

\section{Your next submission with Juniper Publishers will reach you the below assets}

- Quality Editorial service

- Swift Peer Review

- Reprints availability

- E-prints Service

- Manuscript Podcast for convenient understanding

- Global attainment for your research

- Manuscript accessibility in different formats

( Pdf, E-pub, Full Text, Audio)

- Unceasing customer service

Track the below URL for one-step submission https://juniperpublishers.com/online-submission.php 